\title{
Interview
}

\section{Grammar instruction and writing skills at secondary school. An interview with Debra Myhill}

\author{
Marina Casadellà \\ Universitat Autònoma de Barcelona, Spain
}

Text received 20 May 2014; final version 30 May 2014

\begin{abstract}
Debra Myhill is Associate Dean in Research and Knowledge Transfer at College of Social Sciences and International Studies, University of Exeter (UK) where she is the Subject Leader of English with Media. Her research interests are principally in the field of language and literacy, with a particular focus upon the teaching of writing; teaching of grammar; gender and literacy; and talk. She is co-editor of the book Becoming a Designer: Trajectories of Linguistic Development, published by Sage in 2009.
\end{abstract}

INTERVIEWER: Nowadays, there is a general international concern about standards in writing. In your opinion, what is this debate like in the UK context?

MYHILL: In England, we know that students achieve less well on national writing tests than they do on national reading tests. For example, at age 11 there was a $3 \%$ gap between reading and writing attainment in 2013. However, the national concerns are frequently based on popular opinion rather than hard evidence - politicians and news editors often like to argue that young people today are poor writers, usually based on anecdotal evidence. What we know is that over the past 15 years standards in writing have been steadily rising. However, there is a more complex issue at the heart of this. Assessing writing, as research has shown, is not objective and what constitutes 'good writing' is not a consensual construct. It is both subjective and socially constructed. And, of course, ideas about what good writing is change over time. When I was assessed at age 16 in the national test of English (GCE O level) in 1977, all I had to do achieve a good grade was write a composition in an examination, stimulated by a prompt question. Now students have to write in several genres. At the same time, in England, there has been a national trend outside of school for writing to become less formal, and not surprisingly this is mirrored in students' writing. So my own view is that there has been no major decline and our young people are probably more communicative and dextrous writers than any previous generation.

INTERVIEWER: In the public arena some are asking for a return to grammar instruction as a way to enhance students' writing skills. According to a general feeling these skills are lower than ever due to the lack of grammar instruction as well as of 'discipline' in school. What is your position? 
MYHILL: In the public arena, in England, at least, grammar is always raised as the solution to putting right all the ills and wrongs in young people's writing. There have always been language mavens, whose sense of indignation at the linguistic crimes committed in the present era is overwhelmingly strong. Sometimes, they are simply trying to stop the tide of language change. It seems that in every age there are those who long for a golden age, when everyone wrote and spoke beautifully. This age, of course, never existed! The advocacy of grammar as the panacea for writing problems tends to focus very much on error and inaccuracy, and there is often confusion here between a grammar rule (such as, 'Verbs agree with their subjects') and a principle of usage (such as, 'You should not end a sentence with a participle'.)

I have no objection to teachers pointing out to young writers if they have made a grammatical error, but my own experience of reading and analysing thousands of students' written texts means that I know there are very few grammatical errors in the majority of first language writers' texts. The most common ones are the could have/could of confusion and I/me confusions. A much bigger issue, which does have a strong grammar connection, is the use of non-Standard English. Here I think we should be encouraging young writers to develop code-switching competence so they know the differences between Standard and non-Standard English and can confidently choose which is most appropriate.

INTERVIEWER: Although grammar is considered by some authors a content of utmost importance to master writing skills, some studies (mostly experimental) have claimed that there is no evidence that grammar instruction may help students to improve their texts. The implications of this are that grammar is not so important. But the implications of your studies regarding grammar instructions are different. How do you argue about the importance of grammar?

MYHILL: There is a substantial body of research which has been unable to find a benefit for grammar instruction on students' writing, and although it has been criticised on various methodological grounds, I think the overall finding is correct. Simply teaching children grammar, especially if that largely means identifying and labelling grammatical constructions, is unlikely to alter a learner's understanding of language in use. Our own research has been very different in focusing on the teaching of writing, and bringing grammar into the teaching when it has a pedagogical purpose. The goal is not to develop writers who can label grammatical constructions but to develop writers who understand the rich variety of linguistic choices available to them. We have called this 'a repertoire of infinite possibilities', partly to counter-act the prevailing view of grammar as antithetical to creativity. We argue that teaching grammar in the instructional context of writing is supporting the development of metalinguistic understanding and helping to foster writerly decision-making on the part of the writer. In our approach, a teacher's starting-point is either an identified writing need in her class, such as for example, narratives which are too action-driven with little descriptive 
detail; or it is the particular demands of the writing genre being studied, such as, for example, considering the effect of modality in an argument text.

INTERVIEWER: Some of your recent studies highlight the importance of focusing on specific discursive genres (such as poems or narrative texts) to help students apply their grammar knowledge in the context of writing. Do you think that 'genres' are a promising territory to be explored by research on grammar instruction?

MYHILL: The curriculum in England since 1998 has placed a strong emphasis on teaching different genres of writing, and one element of this has been the teaching of the prototypical linguistic characteristics of each genre. This draws heavily on research and professional practice from the Sydney School in Australia, where they have done a lot of work on the grammar of genres. This adopts a Hallidayan perspective, which is all about function not form, and looks at the way in which grammar choices subtly shape meanings. Our own research is very much attuned to this.

I think there are some pitfalls to this approach, however, if the genres are taught too rigidly. In England, we have developed a tendency towards some rather formulaic teaching of writing which suggests 'recipes' for particular genres which should be followed. This is rather limiting. Very few 'real-world' texts conform exactly to all the genre characteristics for that genre and many are hybrids, effectively appropriating elements of several genres. So it is important that young writers understand differences between genres but also the many ways in which these can be used in authentic texts.

INTERVIEWER: Terminology and specific metalanguage are issues of great controversy in grammar teaching. What is your position? Do you think that in the UK there is a general consensus on the role of terminology in the teaching of grammar?

MYHILL: There has been a long history of controversy over grammatical metalanguage, both in terms of whether it has any value at all and which grammar should be used. In general, in England, any discourse about grammar teaching would usually mean using grammatical metalanguage. In the nineties, there was a big emphasis on 'Knowledge about Language ' (KAL), which allowed teachers to engage in language study without grammatical metalanguage, but recent curricular changes have largely ended this. The current National Curriculum, just becoming statutory, is explicit about the need for the use of metalanguage, and grammatical terms which children are expected to know are specified for each year group in primary school. Despite this, I do not think there is a consensus on the role of terminology and many teachers would not teach the terminology if they did not feel obliged to. My own view is that access to grammatical metalanguage is an advantage, allowing precise discussion and analysis of language, and would always be an advantage to have access to it. However, I would not want the metalanguage to get in the way of learning about writing. In our research, we encourage teachers to use the terminology but not to get waylaid by lengthy explanations and exercises, but simply to give model examples to explain the structure which writers can imitate in their own writing. Our current study is following a group 
of 9 year olds and 11 year olds for three years, investigating how they acquire conceptual understanding of grammar. This is suggesting that with younger children, explaining with authentic models and inviting imitation and adaptation, is more beneficial than an excessive emphasis on the terminology and definitions.

INTERVIEWER: It is said that teachers in the UK have in general terms a low proficiency in grammar but important measures have been taken to overcome this problem. What is the situation at the moment? What measures should be taken, in your opinion, regarding in-pre-service teacher education?

MYHILL: I guess by this you mean explicit knowledge of grammar, not that teachers are poor users of language! Grammar has not been an active part of the language curriculum in the UK since the sixties, and although there have always been teachers who did include grammar in their lessons, many did not. As a consequence we have a huge number of teachers who are not confident in their own explicit knowledge of grammar. It's worth noting that the academic calibre of secondary English teachers and of primary teachers in England is very high: it is very competitive to get a place on a teacher-training course in primary education or secondary English. So we have a workforce of very able English teachers. But grammar has not been part of their education. There have been no real measures taken in England to address this, especially since learning grammar is cumulative and undertaken over time: one-off day courses are rarely much help. In pre-service education, there is very little time to address subject knowledge as they spend the majority of the training year in school. But many universities do offer specific sessions on grammar to address this.

INTERVIEWER: In Spain, as a reflection of the continental European context, there is a general agreement about the main goal of language education: to make students competent to handle different situations that require a wide repertoire of language skills. However, the role that grammar knowledge is expected to play in this goal is still not clear. What is in your opinion of the role of grammar skills in a competences-oriented curriculum?

MYHILL: My view is that the role of grammar is to generate explicit understanding of how texts work, both reading texts being studied and the written texts that students themselves produce. As I've already discussed, I don't feel that the principal role of grammar is to ensure accuracy in language production, although if students have access to grammatical metalanguage it does make explaining accuracy much easier. But the real value of grammar is in making visible how language works and how meanings are shaped. From a classroom perspective I am more interested in knowing how, rather than knowing what - I am less interested in naming and identifying and more interested in meanings and effects. When students are learning to write, developing growing understanding of the infinite number ways in which grammatical choices can influence how meaning in created in text enables them to become writers who have more ownership of the writing process and can make their own choices. In England, the 
teaching of literature routinely includes teaching students about literary metalanguage (eg metaphor; alliteration; caesura) as a way of talking about and understanding literary texts. For me, grammatical metalanguage is the natural complement to this and often opens up new ways of analysing and reflecting upon texts.

INTERVIEWER: Some authors have claimed that a perspective wider than a linguistics approach should be taken if we want to develop a school grammar contingent to school needs. In your opinion which perspectives should be taken into account to complement a linguistic perspective?

MYHILL: I think it is very important to think of the needs of learners when considering how grammar should be integrated within the curriculum. My own experience of learning grammar in England (when it was still taught!) was simply learning how to label and identify linguistics constructions: in effect, learning about language as a system. It is metalinguistic knowledge for its own sake. There is nothing wrong with this, of course, if curriculum policy decides that it values this - it is the same as deciding that children know the periodic table in Chemistry or understand what photosynthesis is. But it is important to appreciate that this kind of knowledge, as evidenced by numerous studies, is unlikely to alter students' competence as language users. For me, I am primarily interested in how grammar can support learning about language so I am very interested in appropriate pedagogies for embedding grammar meaningfully. In our own research, we have placed particular emphasis on high-quality talk as a tool for learning about language and our analysis of classroom talk suggests that this is critical in bridging between the teacher's knowledge and students' own independent knowledge: it is the talk which co-constructs meaning. We are also currently researching how students develop conceptual understanding of grammatical metalanguage, and the inter-relationship between this and teachers' practices. Both these areas are ripe for further research.

INTERVIEWER: Thank you very much.

\section{References:}

Beard, R., Myhill, D., Riley, J., \& Nystrand, M. (2009). The SAGE handbook of writing development. London: Sage.

Author references:

Marina Casadellà is a $\mathrm{PhD}$ candidate at the Universitat Autònoma de Barcelona where she works as a research assistant for the group GREAL: Grup de Recerca sobre Ensenyament i Aprenentatge de Llengües.

Email: marina.casadella@uab.cat

To cite this article:

Casadellà, M. (2014). Grammar instruction and writing skills at secondary school. An interview with Debra Myhill. Bellaterra Journal of Teaching \& Learning Language \& Literature, 7(2), 89-93. 